л. А. Выговский, Т. В. Выговская

Хмельницкий университет управления и права имени Леонида Юзькова, Хмельницкий, Украина ЭКОЛОГИЧЕСКАЯ СОЗНАНИЕ

КАК ОСНОВА ЭКОЛОГИЧЕСКОЙ КУЛЬТУРЫ ЛИЧНОСТИ

Доказывается, что в условиях глобальной экологического кризиса очень актуальна проблема формирования и повышения уровня зрелости экологического сознания личности. Подчеркивается, что в системе такого сознания мировоззрение выполняет системоформирующую функцию, поскольку дает человеку ответ на вопрос о смысле жизни в контексте экологической деятельности. Раскрывается роль исторических типов мировоззрения (мифологический, религиозный, научный) в контексте такой деятельности, аргументируется положение о том, что характеристика основных уровней сформированности экологического сознания индивида одновременно является и характеристикой уровней ее экологической зрелости. Это обусловлено тем, что типологические группы отражают степень восприятия экологических идей и усвоения экологических принципов с последующей реализацией в экологической деятельности. Утверждается, что можно выделить три основных уровня экологической зрелости сознания личности: наивнореалистичный, буднично-эмпирический и сознательно-теоретический. Наивно-реалистичный уровень зрелости экологического сознания присущ людям, которые в жизни ведут себя как стихийные экологи. Доказывается, что для буднично-эмпирического уровня характерно отсутствие (в рациональной и эмоциональной сфере) негативного отношения к экологическим проблемам. Доказывается, что для сознательно-теоретического уровня такого сознания личности характерное осознанное и активное отношение к решению экологических проблем.

Ключевые слова: мировоззрение, экология, сознание, экологическая сознание, мифологическое мировоззрение, религиозное мировоззрение, научное мировоззрение, экологическое сознание, уровни экологической зрелости сознания человека.

Leonid Antonovych Vyghovsjkyj, Tetjana Viktorivna Vyghovsjka

Leonid Yuzkov Khmelnytskyi University of Management and Law, Khmelnytskyi, Ukraine

\title{
ECOLOGICAL CONSCIOUSNESS AS THE BASIS FOR PERSON'S
}

\section{ECOLOGICAL CULTURE}

The article shows that in the conditions of global ecological crisis Homo sapiens as a species can only survive if the problem of restoring historically lost balance of relations in the general system of "human being - natural environment" is resolved as soon as possible. We argue that such a process requires, first and foremost, an appropriate reorientation of the humanity's worldview with respect to the nature and formation of environmental consciousness in members of the human community based on such principles. It is proved that in the system of ecological consciousness the worldview plays a systematic role, because it gives a person the answer to the question about the main values and priorities in human life, provides appropriate ideological justification of thoughts and actions that meet the ecological needs of people and communities. It is emphasized that, in such a situation, the preservation and restoration of the environment, which forms the need for ecological activity, becomes a sense of human life. The role of historical types of worldview (mythological, religious, scientific) in shaping the attitude of a person to nature is shown. We also show that the characteristics of the main levels of formation of the person's ecological consciousness is, at the same time, the characteristics of their ecological maturity. This is due to the fact that the typological groups reflect the degree of perception of environmental ideas and the adoption of environmental principles with subsequent implementation in environmental activities. We show that the levels of environmental consciousness can be classified as naive-realistic, everyday-empirical, and conscious-theoretical. The naive-realistic level of maturity of environmental consciousness is characteristic of people who act as natural environmentalists in their lives. The everyday-empirical level is characterized by the existence (in the rational and emotional areas) of a negative attitude to environmental problems. The conscioustheoretical level of such consciousness is characterized by informed and active attitude to environmental problems. It is emphasized that in the process of forming an ecological worldview, there is a need to move from the dominance of the environmental paradigm to the dominance of the ideological, moral and ethical paradigms.

Keywords: worldview; ecology; consciousness; environmental consciousness; mythological consciousness; real-world outlook; scientific worldview; environmental consciousness; levels of ecological maturity in person's consciousness.

UDC 164

DOI:10.17721/sophia.2019.14.9

la. O. Petik, M.A. in philosophy truedarkbodhi@gmail.com

\section{PHILOSOPHICAL PROBLeMS OF THE MENTALISTIC LOGIC}

Paper deals with philosophical problems of mentalistic logic. Mentalistic logic is a formal system that concentrates on underpinning processes of mental life instead of certain elements of extrinsic rational behavior as most of existing logics (like BDI calculi) do. The project is compared to the existing logics of actions.

Mentalistic logic is patually a formal system and partually phenomenological study of human mind. We presume formal signs such as propositions and modal operators refer to mental states and can describe the general structure of mental activity. That is purely the approach of classical phenomenology - the study of experience and its structures. On the other hand the usage of formal logic is a classic analytic philosophy of mind.

So the things are getting more complicated when taking in consideration that the initial framework of a study is analytic philosophy and not continental phenomenology. Phenomenology is of different intellectual and methodological tradition than any type of analytic philosophy including analytic philosophy of mind. From that stanpoint it may be said that paper is also interesting as a purely methodological project - it tries to find bridges between phenomenology and philosophy of mind.

As for the action logics, mentalistic logic also studies rational behavior but does it on the other lever and often with a different purpose.

The main problem in this case is philosophical interpretation of modality. Minor problems include shared content, many leveled self-referential structures and vagueness. The paper also studies brain in a vatt thought experiment as a methodological concept. The research will have implications for philosophy of logic, artificial intelligence and theory of reference.

Key words: philosophy of logic, philosophy of mind, psychologistic logic, folk psychology.

\section{Introduction}

In general, throughout the latest years number of different logics modeling human psychology were built. For example, a belief desire intention (BDI) logic has been used to formalize intelligent behavior. However research for formal systems designed so as to show the underpinning processes of our mental life including complicated abstract thinking is in process. In other words, the formal system which can be called mentalistic logic is a matter of further elaboration.
This paper deals with the philosophical and formal problems surrounding the mentalistic logic. These problems can be grouped into two distinct sets. The first set includes problems of the classical logic, which should be solved in order to create a mentalistic logic. These are the problems of completeness of such a system in relation to the particular features of the mental processes it should represent.

Another difficulty from this set is more technical: how to adequately present psychological notions with modal operators. There are existing schemas for formal systems 
centered on behavior but mentalistic case presents far higher demands.

The second is about the new problems, which appear for the classical laws of logic when formal system is enclosed to represent the mental. They can be grouped into three particular issues: vagueness, many leveled and self-referential structures and shared content.

Vagueness is a fundamental notion for mental processes. Daily perception of things surrounding us and objects of abstract thinking are vague. On the other hand, properly and strictly defined object belongs to the domain of pure mathematics. Number of special so-called fuzzylogics was created to represent imprecise reasoning. These logics are not enough for the global aim of representing the vagueness in logical notions.

Complex structures appear every time when abstract thinking is involved. This is not a mere intuition connected to the famous paradoxes of the mathematical logic but a strong trend in contemporary philosophy of logic, for example - the two 'layered' semantics of the Levesque's belief logic and his followers [6, p. 95]. Another example is the touchstone influence of the fixed points in general mathematical logic. To sum up there is a development of double-level semantics, which is quite popular in philosophy today, and besides it we can use modal semantics for presenting complex informational structures.

Conception of the shared mental content comes from the philosophy of mind and it is connected to the previously mentioned problem of adequate modal operators. We presume that extensive process of the exchange of information is happening in human brain. It means two things. The first is that this information is encoded in some special way. But in what way in particular has been discussed by different theories of mental representations. The second is that the mind, according to popular metaphor of Daniel Dennett, is like a blackboard shared by several experts [3, p. 8]. Then, formally mind is represented by the set of propositions shared by different "agents" and possible worlds in the brain activity.

A modal logic built on those principles will of course strongly resemble the simplest artificial neural networks. This and according implications will be also the point for discussion.

Solution of these and some minor problems will be an aim of a paper. It will present few interconnected ideas in philosophy of modal logic which should help with the problems.

\section{Modality and mental}

How to apply modal semantics to mental content? The interpretation according to which modal worlds are causally isolated universes seems to be inappropriate for the case of the mentalistic logic.

Most of the logicians whose elaborations are connected to psychology and behavior use to deal not with possible worlds but rather with situations. Situation as it is natural to suppose describes only the part of the world on the certain stage of its history.

The agent or the group of agents has an access to the lists of propositions, that describe particular situations and depending on the chosen formal system, they are supplied with one or another corresponding activity. There is an initial situation and a decision can switch an agent to one of further accessible situations. Situation is good term for action representing systems.

However if the relatively simple rational behavior is not adequate for the purposes of the research, notion of the situation is not enough. The target of the presumed model is not behavior but mental process behind it. Situations on the other hand are applicable only to the extrinsic environment while our aim are intrinsic mental structures. So the modality in this case should acquire a new philosophical interpretation.

This is the case when the interpretation of the semantics really matters. In BDI-logic knowledge bases are used instead of situations. It shifts the purpose and structure of the formal system dramatically. Some elements of the inner mental world of the agent are presented in BDI logic and it is much more close to our purposes.

Knowledge base is defined and extensively used in logics of beliefs. Belief is one of the fundamental parts of the folk psychological theory of mind and many special properties of this kind of notion are described in existing philosophy of mind. Beliefs are the main part and defining mechanism of the mind according to folk psychology. It is logical to presume that building the framework of mind should be started from the notion of information encoded by agent's beliefs. Yet this is the first point where the old approach faces problems.

The first problem is how to represent the shared mental content. If we admit the previous notion of belief, we cut the possibility to provide the model of a shared informational space. We have to leave the possibility to say that agent believes " $p$ " and agent imagines " $p$ " with the very same meaning represented by proposition as the content of a mental state. This requires completely different structure than the one built within belief-related logics. So we postulate the problem of usage of propositions in contexts of mental. Knowledge of a belief base should be just one of the modes of the mental activity. Besides, if we preserve the belief-centered system it is doubtful whether it will bring us anywhere. Most of the logics that incorporate beliefs as a separate knowledge base follow the same general structure.

It is indeed true that while having a positive function, a concept of the shared mental content can have disadvantages. If we presume that everything there is in mental content should be described by propositions we inevitably meet the problem of the adequacy of propositions. We've just postulated that propositions should not be divided into modal categories and in addition we assume that they should be applied to all kind of objects and relations both intrinsic and extrinsic to mind

What can be so complex that it cannot be represented by a proposition or a set of propositions? Consider the example from psychology when the unforeseen and exotic fact while being cognized changes the whole picture of certain situation or even general views on the world. We cannot present it as a gradual change in the formal system - first of all because of the number of propositions involved secondly because the change may be so global that it does not just influence the relations between propositions but rather introduces other ones etc.

We also should take into account that there can be other examples different in structure but with similar negative consequences. What can be said in defense of the proposed idea of the mentalistic logic besides attacking it? The examples should all be considered in particular and while no exact formalism or example from science of psychology ruining the system is produced, we should not deny the idea of mentalisitic logic. Some parts of content of the propositions can be eventually formalized so as to represent the discussed complex objects as it was with the earlier logical systems. The resolution of the described difficulty may lie in the same field. Then we will have only to modify the existing system. However the problem should be reacted accordingly when it is defined.

So we need a basis for the new philosophical interpretation of modality. More effective and adequate 
structure for mental modalities is possible and in order to illustrate that we need to analyze the next example. We need philosophical interpretation for the worlds in a multiagent system with a shared content. In a thought experiment that follows illusion produced by data and levels of reality represent the situation of mental quite well. Thus worlds as formal entities will receive a proper candidate for philosophical ontological interpretation.

\section{Brain in a vat}

Imagine a situation of a well-known "brain in a vat" thought experiment. There is a scientists John who is conducting experiments on a living human brain put in a vat and connected to a computer that provides the neural tissue with a complete illusion of the real world. The brain has beliefs as if he was actually a human named Bob living in a separate world, from the one where John exists. It is not hard to build a formal model of this situation using modal semantics. There are two worlds John's world and Bob's world, which are connected by the classic accessibility relation. However propositions that describe these worlds are different and it is hard to establish a connection between them similar to those in other philosophical logics. It may be true that "Sun is shining" in the Bob's world while completely another proposition describes the situation in the John's world and any logical connection between two would be random. Thus the semantics cannot postulate box or diamond-like operators. Nevertheless there are relations of the other kind common for these two worlds.

From the point of view of John, the world of Bob is not real. The proposition $p$ of the Bob's world stating that "sun is shining" does not state something real about the John's environment. Instead it is true that q for John - "it is raining". But John has the access to the information about state of affairs of the Bob's environment. He can say that "according to the sensory data that Bob's brain is receiving " $p$ " is true". In other formulation it can be said that all the propositions about Bob's situation can be transferred to the John's world using special clauses. So it is true that $q$ and that " $p$ " for John.

So how it is relevant for the mental world? It is a model of how mind works. We presume that mind is a multi-agent information exchanging system. Bob and John are different mechanisms of the mind, which are presented by separate modal operators in the behavioristic logics. They are experts according to Dennett's metaphor. However in a given case we do not need to use different sets of worlds for each of the modal operators as well as modal operators themselves at least for now. Modules of the mental will be presented by separate worlds in a unitary set of the worlds so we will have one global knowledge base.

So John's world may be imagination while Bob's world is memory. The processing of the claused propositions in the John's world represents a cooperation of imagination and memory, which is one of complex multi-leveled structures. The other examples of such complex structures include fixed points in mathematical logic, formal models of the semantic paradoxes and parallel processing in computer science.

The whole mental world can then be presented as a set of the interconnected worlds where centered world contains information while accessible worlds are different mechanisms of mental activity. These mechanisms include imagination, memory, abstract thinking, language processing.

The centered world is pure - it does not bare any function as the world except providing the surrounding sphere with information. Other worlds bear each a separate function with them. The propositions within the world of the imagination are not the same as in the world of the language processing. However it is evident that certain set of the propositions is exchanged between these two worlds. You certainly humans need the ability to imagine objects and concepts in order to construct phrases. The exchange of the information happens through the medium of the centered world.

Such a centered word is connected to the study of consciousness. After all we used the Dennett's metaphor for describing the multi-agent system [3]. The obvious thought is to say that consciousness in a sense of Chalmers and its unstudied informational properties is a key to explaining the difference between a machine and human intellectual agent. But the phenomenal level of experience is an open problem in contemporary metaphysics and philosophy of mind. Some philosophers admit it, while others don't and all of them disagree on what are the properties of this entity in particular. There is no clear way to introduce the influence of Chalmers' conception in a logical formalism without harming either formalism or philosophy. So this is not about hard problem of consciousness. It is rather about general psychological awareness of the individual.

Classical modal logic present different geometrical relations between worlds like seriality, transitivity, euclidianity. Not all of these relations are applicable to the given system. Reasons for that are both philosophical and formal.

There is a strong evidence in cognitive psychology that some of the modules of the mind are encapsulated, which is in a great contradiction with a classical equivalence relation. Not all of the propositions from some module $X$ are accessible for the general consciousness while being processed. Much of the evidence shows that relation between informational processes in the brain is not that straightforward as they are in the classical semantics. The formal model should reflect it as well. The unity of the relation is also under question as different mechanisms require different approaches. You have one kind of the relation within the module of memory and another kind of relation within imagination. So it is impossible to provide a classical modal algebra for the operators.

As well it is problematic to present the mentalistic framework with the classical geometrical relations formally but due to another reason. As it was already stated above the relations between agents in this system are not just inadequately reflected by classical relations between modalities but rather they are based upon completely another foundation. These are the clausing relations between the worlds.

Unlike in the John's and Bob's example there seem to be a lot of cases in the cognitive system when propositional content is the same for many worlds. We can return to the analogy with memory and imagination. You can imagine a red apple on the table in front of you as well as you can recall the image of seeing such a thing in the past. Cases presume different worlds but same propositional content an apple on a table. This content is shared by modules, which may be the key to explaining how imagination infiltrates and influences our memories. More globally this sharing plays an important role in the whole mind not just in connection to these two modules. There is no need to deny such peculiarities of the real thinking in our formal structure. Besides if the shared content is a real tendency of the mind, it only affirms and strengthens our model. This is a hypothesis of a philosophy of psychology but it still needs to be represented formally.

Nevertheless a case with an apple is not a sign of the principal flaw in the chosen metaphorical description of the 
framework. Both cases can actually be represented in the thought experiment. What is more important the experiment provide with a general tool for analyzing the relations between propositional content of the worlds. This will be in accordance with the multi-agency of the blackboard theory. So as was stated earlier the propositions from the Bob's world will be present in the John's as claused propositions. John has an access to the world of Bob - he knows what happens in the Bob's reality while Bob knows nothing of the John's world. It is a proposition "p" in John's world about Bob's - "it is raining" or "it is true in the Bob's world that it is raining".

This is a sort of epistemological relation, which can be applied in the multi agent system. The world of John is higher in hierarchy of worlds and the according relation grants John's world access to the propositional content of Bob's in form of the list of claused propositions. This does not seem like any of the classical relations between modalities but it is a certain relation which can be represented formally. It is an epistemological arrow pointing from the Bob's world to the John's. In the case of the cognitive system these arrows will point from the central world to the ones representing modules. The according arrows from the encapsulated modules will be regulated by valid circumstances. Here we come to the line from which the example with the brain in a vat experiments is not valid anymore. We can of course imagine a tree of worlds when John is a brain in a vat himself. A part from being unnatural this example provides only with upper growing line of worlds. This particular case requires branches in such trees - the worlds that will relate to some central node while being equal in relation to each other. When we try to modify the thought experiment with some branching elements it starts to look even more unnatural. We should admit that this metaphor did its prior role of given philosophical interpretation of the worlds. The picture of the mind as a set of worlds is presented and we can move on with it.

Certain hierarchy was mentioned. Modules of the mind create sphere surrounding pure central world, which is defined by the accessibility relation. It may be useful for instantiating the global relations between worlds not just the central and the surrounding spheres. There should be connection not only of the centered world but also between modules especially if we keep to the idea that the central world is a useful abstraction rather than a representation of consciousness or other concept. In a case of classical modal logic we have to deal with the unconstrained number of worlds that can form the big number of spheres. In a given case the number of worlds at least those of them that are conceptually required is limited. The class of modules and abilities of the individual brain is definitely finite. However we may assume the existence of the worlds that will play technical role and not conceptual - they can be of big quantity and even infinite.

\section{Awareness and modality}

The further important question arises - what semantic relation we define for outlined features and what modality it will create. Described peculiarities and used thought experiment seem to point that this semantic relation will define the accessibility of the information for modules of the mind. If we require the philosophical interpretation then this schema will show of what propositions the mind of the agent is conscious. As was stated earlier the consciousness in philosophical sense is too strong to be formalized in this way but there is a close similar notion proposed by David Chalmers [1, p. 15]. It is psychological awareness. The brain is aware of certain things like a red apple on a table in front of him or the fact that he is not dreaming etc. The notion refers to purely functional role of the information in concerning the particular agent. Everything of which agent is conscious of he is also aware of. It made Chalmers to propose the conception of the double life of mental terms. In a given case notion of awareness means literally the accessibility of the information encoded into propositions for the processing of different mechanisms. This will serve as a good philosophical interpretations and will block metaphysical problems connected to issue of consciousness of philosophy of mind.

The next problem is to choose a corresponding modal operator. For this we can use the ideas from both the classical modal logic and multimodal logic describing planning and behavior. From the first sight it seems logical to presume existence of the operator analogous to the boxnecessity from the classical modal logic which will define a proposition existing in all the worlds of the sphere. But is it a good choice? What will be the exact philosophical interpretation of the necessity operator in the scope of the mentalistic logic? There should be some propositions that will be accessible both for the central world and for all the modules of the mind but there will be very few. Brain does not share all of the information among all of its parts. If we return to our conception of the claused propositions this box operator will define unclaused ones.

What processes will be represented by unclaused proposition, which exist only in a separate module? For example, if I see something of the relevant class it will influence all other feelings and intellectual capacities of my body.

Let us assume that it is possible - and indeed psychology presents with certain examples of extremely stressful situations that affect the whole organism of the agent while being introduced only through some of the feelings. The dangerous predator in the visual field of the agent may influence processes of metabolism and indirectly hearing and some mental states. Persisting and long term physical or mental stress can bring hallucinations and even serious mental disorder that will affect the whole organism as well. However these are all extreme and borderline cases. Formalizing them may be interesting but should not be the main aim. Many classical psychological theories are built while exploring the effects of the actual mental abnormalities. But mentalistic logic is about thinking of the regular human agent in relatively regular circumstances.

Besides, what will be the function of this operator in the general picture if its statements will be so few? It is also hard to imagine such propositions that will be valid for all modules of the brain if we are taking in account cognitive science data and relevant works of $\mathrm{J}$. Fodor and other contemporary philosophers of mind [4, p 5.]. Even if we turn to the problem we started from - the Dennett's metaphor - it represents mind as a blackboard but states existing of the different distinctive agents-experts. Brain is evidently a set of different mechanisms which while remain cooperative are definitely separate. The things may change if we are speaking not about brain but about mind; presenting mind as an entity, which exists separately from underpinning physiology and has a different main feature is adopting metaphysical dualism.

The idea of unclaused propositions is also interesting for the philosophical theory of reference. What are the statements that mind is absolutely aware and which are such for every module? We have certain analogy with classical logic where there are such "absolute" statements - tautologies. The statements similar in the form to " $X$ is $X "$ should be a good candidate for the boxpropositions of the mentalistic logic. Mentalistic logic is in 
majority non classical calculus but thanks to assumed box-operators we can introduce rules of the classical logic into our system and make it an extreme case of mentalistic logic. This is quite important and interesting as it shows that modalities in a given case can make logic more general rather than more specified.

As was stated in the introduction the described structure will resemble the simplest artificial neural networks (ANN). It can be applies both to the case of the schema describing flow of the information between different ANN and the case of processing of the information in the particular ANN. The interesting question is why so? Is ANN principal structure is intrinsic to the functioning of the brain? Another interesting detail is that it opens the possibility to describe higher order computational processes of the brain tissue using formal language.

\section{Vague notions and fuzzy logic}

There exist a class of logics and formal semantics that formalize imprecise contexts. They are called fuzzy logic. Fuzzy logic has disadvantages from the point of view of philosophical interpretation of the vagueness itself rather than from particular formalism. I see vagueness as a notion closer to the phenomenology of consciousness than to the specific ranges of precise value.

Vagueness in the context of mentalistic logic is useful when it is viewed differently. I see the table with an apple on it in front of me but my sight is bad or I am tired and I do not see it precisely. The situation is so bad that I can't say definitely if it is even an apple. Maybe it is some kind of another fruit. What I can conclude is that there is an object of a certain shape resembling an apple in front of me. There are two distinct features of the event here. First is that I cannot say that this object is an apple and therefore I classify it as a more general object - "an object resembling apple". The second is that there is a possibility of confusing the object with a similar one. Confusion is usually connected to resemblance and forms a class of similar objects. Some of the objects resemble apple more than others so the probability of confusion with them is higher. These two features are usually formalized in fuzzy logics and other formal systems with the help of the mentioned ranges of values. It concentrates only on the second feature and does not represent correctly even it alone, so it is not satisfying.

In addition it should be said that range representation is wrong from the very beginning when it starts to assert that the mathematical range of values will represent what happens to an agent and apple. What is fuzzy range of values? Simple ascription of the range of values instead of the particular value. Seeing the apple and confusing it with something else is phenomenology and not mathematics. It is impossible to use an exact range of the similar objects to show how the vagueness in perception works. When we have rough experience at hand the situation is different than just a choice of a value on a range. It is indeed true that most of the agents will respond with one of the presented values but while orienting on them we are losing the possibility to describe the real mechanism of mental process.

\section{Conclusion}

A paper deals with the classical problems of logics connected to mental states and proposes to build a new formal system that will represent intrinsic mental states. Certain new methods such as many-leveled structures and vague notions are discussed.

In general this paper is a survey of the philosophical problems and methodology that surrounds the logic that puts at center mental world of human beings and their behavior.
In conclusion it can be said that introducing the box operator in a proposed way will make formal system very specific - it will be the logic that will represent the awareness of the agent. It would be a step to representing mind as the system of propositions connected by associations rather than strict logical laws. Classical logic than remain serving as a small core or even a separate module of general thinking. However these are not the presumed aims within the mentalistic logic itself.

Perhaps the better way to introduce the ideas of the classical modal logic to the mentalistic system is by using some kind of the synthesized variant of necessity and possibility - the modal operator that will describe the partial nature of the accessibility of the portion of the information for the modules of the mind. This is especially relevant in the context of the general vagueness of the system. The modality will be vague if the semantics of the operator is established as proposed. Even richer results could be achieved if we combine the classical modality with the modality as given in action and behavioristic logical systems.

So the other way to present the system is to use behavioristic logics like mentioned BDI calculi, doxastic and action logics [7, p. 355]. Naturally from this point of view modal operators will represent the actual modules of the mind and will be tight to the relevant worlds. So operator BEL for example will represent the knowledge base and IMG the ability to use imagination etc. This is simpler and more promising but still would involve many complications. Such operators should be connected with each other by special modal algebra like classical necessity and possibility are. Most logics just preserve to the classical schema when necessity is defined through possibility and vice versa - only the names of the operators change while the widely known algebraic relation remains the same.

There might be brought new breath into idea of the box operator if we connect it with these new modalities. The box operator or the partial box operator can be the result of the combination of the operators devoted to the modules of the brain. This will establish a new original modal algebra instead of the classic one. Philosophically the modality in the system will represent the exchange of the information between different agents just like stated in the initial Dennett's metaphor. The brain is not omniscient because the information is flowing in its different regions and is processed in them separately. A part from that it explains the contradictions in belief-reasoning.

Together with all of that we should say that there is no formula that will adequately present the whole space of solution of the real experience. But there are ways to produce a more suitable version of the semantic range for the vague cases of mental processing. It is again a field of complex structures. Systems of ranges and particular ranges still will be used. Each is qualitatively different from others so they cannot be presented as members of one range. The structure that will define the rules of switching between such range will be a better choice for mentalistic logic than a simple fuzzy formal system.

Список використаних джерел:

1. Chalmers D. J. The Conscious Mind: In Search of a Fundamental Theory / David Chalmers. - New York ; Oxford : Oxford University Press, 1996. $-432 p$.

2. Chalmers D. J. The Content and Epistemology of Phenomenal Belief David Chalmers. // Consciousness: New Philosophical Perspectives Oxford : Oxford University Press, 2003. - P. 220-272.

3. Dennett $D$. Toward a Cognitive Theory of Consciousness / Daniel Dennett // Brainstorms: Philosophical Essays on Mind and Psychology. Cambridge, MA : MIT Press, 1978. - P. 163-188.

4. Fodor J. A. The Modularity of Mind / Jerry Fodor. - Cambridge, MA : MIT Press, 1983. - $145 \mathrm{p}$

5. Kyburg Henry E. Jr. Probability and the Logic of Rational Belief / Henry Kyburg // Middletown, CT: Wesleyan University Press, 1961. - 346 p.

6. Levesque H. J. On Acting Together / Hector Levestsque et al. // Proceedings AAAI '90, 1990. - P. 94-99. 
7. Lindström S. W. DDL Unlimited: Dynamic Doxastic Logic for Introspective Agents. / S. Lindström and W. Rabinowicz. - Erkenntnis. № $50-P$. 353-385.

8. Odifreddi P. G. Classical Recursion Theory. / P. Odifreddi. Amsterdam : North Holland; second edition, 1999. $-686 \mathrm{p}$.

References:

1. Chalmers D. J. The Conscious Mind: In Search of a Fundamental Theory / David Chalmers. - New York ; Oxford : Oxford University Press, 1996. $-432 \mathrm{p}$.

2. Chalmers D. J. The Content and Epistemology of Phenomenal Belief / David Chalmers. // Consciousness: New Philosophical Perspectives - Oxford : Oxford University Press, 2003. - P. 220-272.

3. Dennett D. Toward a Cognitive Theory of Consciousness / Daniel Dennett // Brainstorms: Philosophical Essays on Mind and Psychology. Cambridge, MA : MIT Press, 1978. - P. 163-188.
4. Fodor J. A. The Modularity of Mind / Jerry Fodor. - Cambridge, MA : MIT Press, 1983. $-145 \mathrm{p}$.

5. Kyburg Henry E. Jr. Probability and the Logic of Rational Belief / Henry Kyburg // Middletown, CT: Wesleyan University Press, 1961. - 346 p.

6. Levesque $H$. J. On Acting Together / Hector Levestsque et al. // Proceedings AAAI '90, 1990. - P. 94-99.

7. Lindström S. W. DDL Unlimited: Dynamic Doxastic Logic for Introspective Agents. / S. Lindström and W. Rabinowicz. - Erkenntnis. № 50 - P. 353-385.

8. Odifreddi P. G. Classical Recursion Theory. / P. Odifreddi. Amsterdam : North Holland; second edition, 1999. - $686 \mathrm{p}$.

Надійшла до редколегії 22.10.19

Я. О. Петік

\section{ФІЛОСОФСЬКІ ПРОБЛЕМИ МЕНТАЛІСТСЬКОЇ ЛОГІКИ}

Розглядаються філософські проблеми менталістської логіки. Менталістська логіка - це формальна система, яка концентрує увагу на закритих процесах ментального життя індивіду замість розеляду деяких зовнішніх деталей рацоінальної поведінки, як робить більшість логік, що існують (як, наприклад, ВDI). Проект такої логіки порівнюється з логіками дії, що існують.

Головна проблема в цьому розеляді - це проблема інтерпретації модальності. Менші проблеми містять загальнодоступний контент, багаторівневі структури, які посилаються самі на себе, а також нечіткість. Також досліджується мисленнєвий експеримент "мозок в бочці" як методологічний концепт. Це дослідження матиме наслідки для фрілософії логіки, штучного інтелекту, теорії референції.

Ключові слова: філософія логіки, філософія свідомості, психологістична логіка, народная психологія.

Jaroslav Oleksandrovych Petik

\section{ФИЛОСОФСКИЕ ПРОБЛЕМЫ МЕНТАЛИСТСКОЙ ЛОГИКИ}

Рассматриваются философские проблемы менталистской логики. Менталистская логика - это формальная система, которая концентрирует внимание на скрытых процессах ментальной жизни индивида вместо рассмотрения некоторых внешних деталей рационального поведения, как делают большинство существующих логик (как, например, BDI). Проект такой логики сравнивается с существующими логиками действия.

Главная проблема в этом исследовании - это интерпретация модальности. Меньшие проблемы включают в себя общедоступный контент, многоуровневые и самоссылающиеся структуры, а также нечеткость. Эта статья также изучает мыслительный эксперимент "мозги в бочке" как методологический концепт. Это исследование будет иметь последствия для философии логики, искусственного интеллекта, теории референции.

Ключевые слова: философия логики, философия сознания, психологистическая логика, народная психология.

\section{ІДЕÏ КАНТІВСЬКОї ФІЛОСОФІЇ В РЕЦЕПЦІї УКРАÏНСЬКОÏ ДУМКИ (У ДОСЛІДЖЕННЯХ П. КОПНІНА, В. ШИНКАРУКА, М. БУЛАТОВА, А. САВЧЕНКО)}

Висвітлюеться досвід реконструкції логіко-методологічної концепції І. Канта про норми і правила постановки питань (завдань, проблем) у природознавстві і в науках чистого розуму. Відзначається його епістемологічне обгрунтування проблемності наукового пізнання. Основна увага зосереджена на обгрунтуванні рецепції кантівської філософії в працях П. Копніна, В. Шинкарука, М. Булатова та А. Савченко.

Присвячується вивченню філософії І. Канта в Київському національному університеті імені Тараса Шевченка в 80-х роках ХХ ст. Розглядається значення філософії І. Канта в професійному університетському середовищі і його вплив на розвиток вітчизняної філософської думки.

Суперечливість філософії І. Канта сприяла формуванню різних філософських шкіл, течій і напрямів. Своїм ученням про антиномії розуму він відіграв визначну роль у розвитку діалектики. Прогресивним було і його вчення про роль антагонізмів в історичному процесі. Тільки через їх подолання можливе досягнення найбільшого завдання людського роду - загального правового громадянського стану, а також встановлення вічного миру між державами.

У першій половині XX століття головною течією вітчизняної філософії був ідеалістичний напрям. Місце І. Канта в розвитку вітчизняної філософії, особливо його етичне вчення, було визначальним. Кантівська свобода має в своєму змісті духовні компоненти: філософські, психологічні, релігійні - і визначає місце І. Канта у вітчизняній філософії у 80-хX років XX століття.

Таким чином, розеляд філософії І. Канта у власному самостійному значенні і цілісності, конкретності як самої по собі цінності (не можна ігнорувати, зрозуміло, ту обставину, що вона є складовою частиною німецької класичної філософії), не тільки правомірний, але й необхідний.

Більшість робіт присвячено різним (окремим, індивідуальним) проблемам філософської системи І. Канта, класифікація яких проводиться за кількома ознаками. Як правило, дослідники виходять з поділу творчості І. Канта на два періоди - докритичний і критичний. Простежується тенденція (поки ще слабка) дослідження на методологічному рівні зв'язку докритичного і критичного періодів.

Ключові слова: філософія, категоричний імператив, університетська фрілософія, кантознавство.

Нова українська фрілософія формувалася і розвивалася в інтелектуальному просторі фрілософського факультету Київського державного університету ім. Т. Г. Шевченка (так він тоді офріційно називався), а також дослідному співтоваристві Інституту фрілософії ім. Г. С. Сковороди. Творча співдружність цих установ висуває як своїх лідерів П. Копніна, а потім В. Шинкарука. Навколо них виникає і затверджується "медитативне середови- ще", яке отримало визнання своєї цінності як у творчоінтелектуальному, так і громадянському розумінні. Тому в цій статті буде досліджено проблеми єдності логіки, діалектики і гносеології, причому не тільки в філософії Г. Гегеля, але у філософії загалом. Особливо сьогодні, в епоху "плюралізму", коли різноманіття різних течій і напрямів веде від цілісного фрілософського погляду на світ. 